\title{
THE MAIN FEATURES OF URBANIZATION SPATIAL EVOLUTION IN UKRAINE
}

\author{
Natalia OMELCHENKO \\ Kherson State University, Ukraine \\ natali_omelchenko@i.ua
}

\begin{abstract}
To date, method for analysis of the current socio-economic conditions and development forecasting, approved for the administrative-territorial units, has been used only in predicting the development of the Autonomous Republic of Crimea, administrative regions (oblasts), groups of administrative regions (oblasts), and also for development of planning development schemes of territories. The article proves that this technique may be applied to some other individual parts of the Ukrainian territory, e.g. historical-geographic territories.

The author for the first time applies the method for analysis and development forecasting for the historical-geographical territory of Volhynia. This technique may help provide longtime forecast of the development of historical Volhynia. Also, the article defines the boundaries of the historic Volhynia and its present spatial structure. Administrative districts (raions) have been typed by their level of development, which allowed to identify the existing problems of the regional development and to work out basic ideas for interventions to address them.
\end{abstract}

Key words: historical-geographical territory, region, forecasting, regional planning, city-planning documentation.

UDC: 911.3

\section{ОСНОВНІ РИСИ ПРОСТОРОВОЇ ЕВОЛЮЦІї УРБАНІЗАЦІї В УКРАЇНІ}

\author{
Наталя ОМЕЛЬЧЕНКО \\ Херсонський державний університет, Україна \\ natali_omelchenko@i.ua
}

\begin{abstract}
Анотація: Дана стаття присвячена вивченню розвитку урбанізаційних процесів та їх основних рис на території України. Викладений аналіз регіональних особливостей урбанізації в Україні. У статті показано важливість дослідження урбанізації у соціальному контексті, зважаючи на те, що урбанізація являє собою багатогранний і дуже неоднозначний процес, який, окрім збільшення частки міського населення та інтенсивного формування міст несе із собою трансформацію всієї просторовоструктурної організації життя населення, його якісних характеристик, а також зміну умов і способу життя людей.
\end{abstract}

Ключові слова: урбанізація, місто, міський спосіб життя, псевдоурбанізація.

УдК: 911.3

Вступ. XXI століття характеризується активізацією урбанізаційних процесів та зростанням їхвпливунасуспільно-економічний розвитокбагатьох країн. Все активніше проявляються специфічні риси цих процесів: якщо раніше урбанізація детермінувалася передусім збільшенням кількості міського населення й територіальним розширенням міст, то сьогодні вона трактується як «історичний процес зростання і підвищення ролі міст у розвитку суспільства, обумовлений об’єктивною необхідністю концентрації та інтеграції матеріального й духовного виробництва, форм і засобів соціального спілкування» [5; 7].

Аналіз попередніх досліджень свідчить про те, що феномен урбанізації цікавив багатьох науковців. В географії на соціальних аспектах розвитку міст акцентували увагу такі науковці як: І.В.Гукалова, Л.Г. Руденко,Г. М. Лаппо,І.Маєргойз, Б. С. Посацький, Ю.В.Медведков, Є.Н.Перцик, Ю.Я.Пивоваров, Г.П.Підгрушний, С. А. Покляцький та ін.

Виклад основного матеріалу. Сучасний стан міського простору України є результатом тривалого i складного розвитку, особливостей процесу урбанізації [3]. Процес урбанізації в Україні довгий

(C) Н. Омельченко час формувався під впливом різноманітних факторів, серед яких головне місце належить політиці держав, в склад яких входила та чи інша частина території України у відповідний історичний період. Саме під їх впливом було сформовано більшу частину міст в XVIII - XX ст. Згідно 3 даними Національного атласу України, північна, центральна і північно-східна частина сучасної території країни концентрувала в собі головні міста, які ще 3 тих часів мали сучасні назви (Київ, Чернігів, Житомир, Вінниця, Глухів, Львів, Луцьк, Перемишль та ін.) [1]. Вже $з$ XIX ст. відбувається активне освоєння південної території сучасної України.

До 1918 р. Україна була аграрною країною i у містах проживало 18 \% населення. Інтенсивна урбанізація в країні розпочалася в 1926 - 1939 рр., коли було взято курс на індустріалізацію народного господарства, лише за 13 років чисельність міського населення зросла у 2,4 рази. За 1940 - 1970 рр. чисельність міського населення в Україні зростала вже значно нижчими темпами - за 30 років вона збільшилась у 1,9 разів. 3 середини 50 -х років $\mathrm{XX}$ ст. почався новий етап інтенсивного зростання кількості міст і чисельності міського населення в Україні. На кінець XX ст. частка міського населення становила майже 70 \% від загальної чисельності 
населення. За кількістю великих міст (з населенням понад 100 тис.) наша держава сьогодні посідає одне 3 провідних місць серед країн світу, таких міст зараз 45 [6].

Урбанізація в Україні, як і в багатьох країнах колишнього СРСР, проходила на хвилі індустріалізації. Саме розвиток промисловості сприяв розширенню економічної бази і зростанню старих великих міст, він забезпечив поліфункціональність більшості 3 них, водночас посунувши інші види діяльності, які варто було б розвивати. Як результат локалізації промислової функції на території України у другій половині XX ст. сформувалися ареали високої концентрації населення i промисловості - потужні міські і господарські агломерації. Моноцентричні агломерації (Київська, Харківська, Одеська, Львівська) утворилися внаслідок розвитку насамперед машинобудування, електротехніки та електроніки, транспорту. Поліцентричні агломерації утворилися внаслідок розвитку гірничодобувної промисловості і металургії (Донецьк-Макіївка, Горлівка-Снакієве, Дніпропетровськ-Дніпродзержинськ тощо). Взагалі у другий половині XX ст. просторовий акцент розвитку великих міст знаходився на сході України, що пояснювалось як економічними, так і політикостратегічними причинами [2]. Все це значним чином вплинуло на специфіку формування міського середовища, структуру зайнятості. I на сьогодні у Дніпропетровській, Донецькій, Запорізькій і Луганській областях зосереджено 40\% великих міст України. Але протягом особливо другої половини ХХст. кількісне зростання міст набагато випереджало якісне, і супроводжувалось масовою та інтенсивною міграцією населення, що не призвело до формування усталеного соціокультурного середовища, а 3 точки зору містобудівництва класичних ядер i центрів міст в їх історичній монументальності.

Розглядаючи регіональні особливості урбанізації потрібно відзначити, що багато регіонів України тривалий час «обходили» процеси інтенсивної індустріалізації і урбанізації. Зокрема, Херсонська область, на відміну від індустріальних регіонів Сходу України, досі має більше риси периферійної, більшою мірою аграрної області, ніж урбанізованого регіону. Хоча частка міського населення становить $61 \%$ - це середній показник за регіонами, 11 регіонів України мають менші показники питомої ваги міського населення. Але внаслідок вигідного економіко-географічного положення, розвитком транспортних шляхів, поточних змін геостратегічного значення регіону, саме ця область може відчути значні зрушення у перебігу та якості урбанізаційних процесів.

Починаючи 31990 р., в Україні спостерігався стрімкий ріст міських поселень i значне їх переважання у людності над сільськими, що продовжується і сьогодні (рис. 1). Наразі урбанізація відбувається на фоні депопуляції населення у комплексі із подоланням кризових процесів в економіці. Підтвердженням сповільнення динаміки урбанізаційних процесів $\epsilon$ негативний приріст чисельності населення по всіх найбільших містах України, окрім м. Києва, зокрема прискорена депопуляція в м. Донецьку та м. Дніпропетровську, які вже втратили статус міст-мільйонників. В той же час, існують міста, які продовжують зростати у своїй людності. Це переважно поселення з більш молодим населенням i ті, де міграційний приток з периферії перекриває природне зменшення населення (Київ, Біла Церква, Кам'янець Подільський, Луцьк, ІваноФранківськ, Хмельницький, Чернівці).

За період незалежності, в Україні відбулися i зміни в структурі розселення - певний перерозподіл у співвідношенні міських поселень різного розміру (рис. 2).

Характер протікання урбанізаційних процесів можна оцінити також за коефіцієнтом інтенсивності урбанізації. Його розрахунок здійснимо за формулою:

$$
K=\frac{\mathrm{y}_{\mathrm{i}}-\mathrm{y}_{\mathrm{o}}}{\mathrm{y}_{\mathrm{o}}} 100
$$

де К - коефіцієнт інтенсивності урбанізації у відсотках, $\mathrm{y}_{\mathrm{i}}$ - частка міського населення у регіоні у 2014 р., у - частка міського населення у тому ж регіоні у базовому (1991) році.

В Україні ми можемо виділити 4 групи регіонів, які відрізняються за інтенсивністю зростання міського населення. До областей, де частка міського населення зросла найбільш відчутно відносяться Чернігівська, Хмельницька, Київська і Вінницька області. На іншому боці $є$ чотири регіони, які зменшили показники «офіційної» урбанізації - це Дніпропетровська, Херсонська, Закарпатська і АP Крим. В останніх двох регіонах це дуже суттєве падіння частки міських жителів, зумовлене різними причинами (рис.3).

У сучасних умовах урбанізацію розглядають не лише як процес підвищення ролі міських поселень у розвитку суспільства та процес поширення міського способу життя людей і їх діяльності у просторі, але i як складний соціокультурний процес інтенсифікації суспільних взаємодій у міському просторі.

Варто відзначити, що у більшості постсоціалістичних країн і країн, що розвиваються, у містах часто проживає значно більше населення, ніж вони у змозі «витри-мати» - тут також наявний надмірний приплив населення до міст, але розвиток міст за цих умов супроводжується зростанням неасимільованих у міське середовище i міський соціум жителів і збільшенням розриву між кількістю міського населення i його реальним включенням у міський спосіб життя (за характером зайнятості, рівнем освіти, культури, побутовими умовами тощо). Зростання населення у містах, значно випереджаючи попит на робочу силу у сучасних галузях, супроводжується не тільки абсолютним, але часом і відносним розширенням тих верств, які не беруть участь ні в сучасному виробництві, ні в сучасному споживанні і залишаються, по суті, на узбіччі міського життя. Багато міст в Україні є дуже молодими, їх шалене зростання за радянських часів 


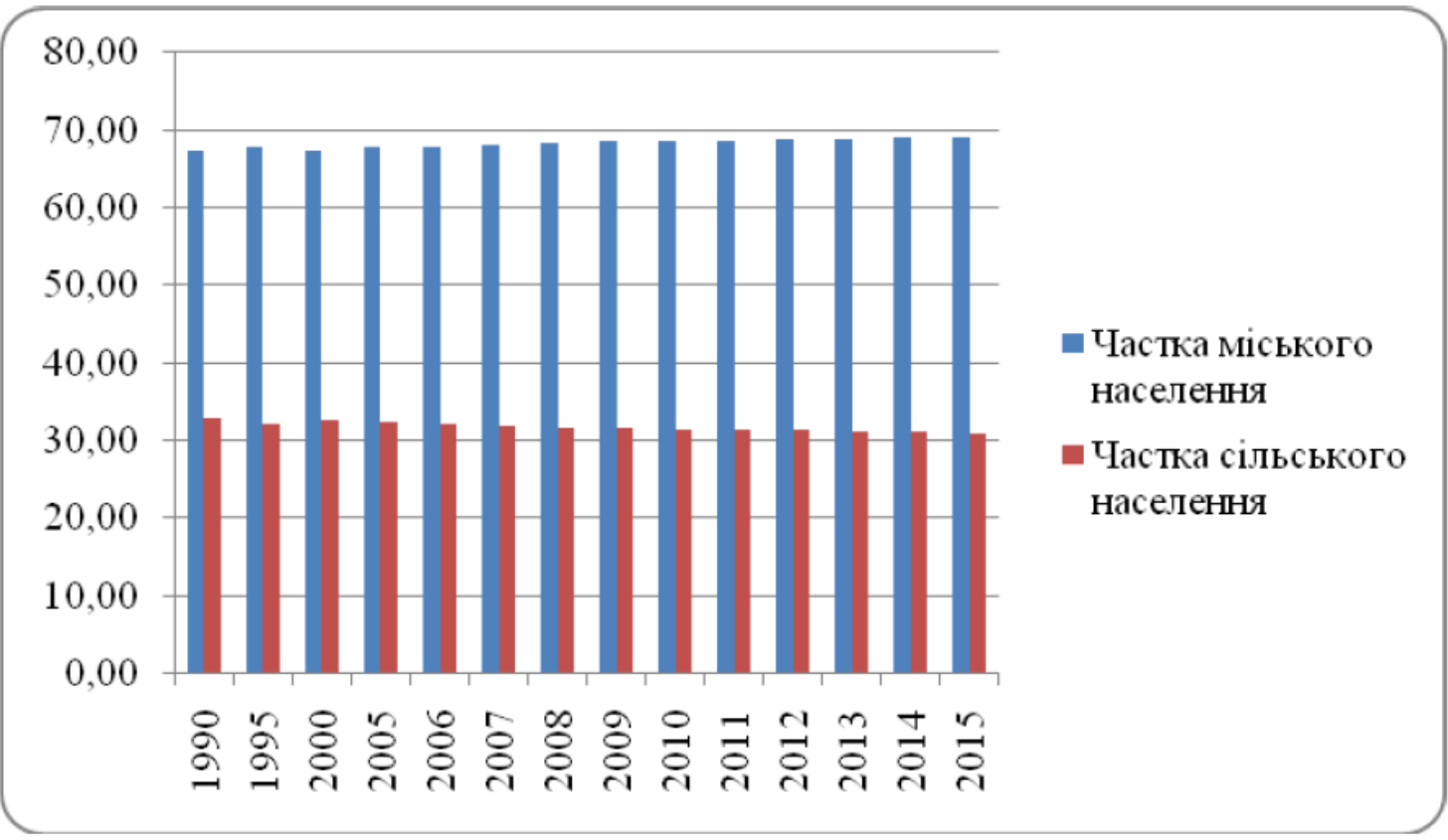

Рис. 1. Динаміка міського та сільського населення України в період 1990-2015 рр. у \% 1991 рік

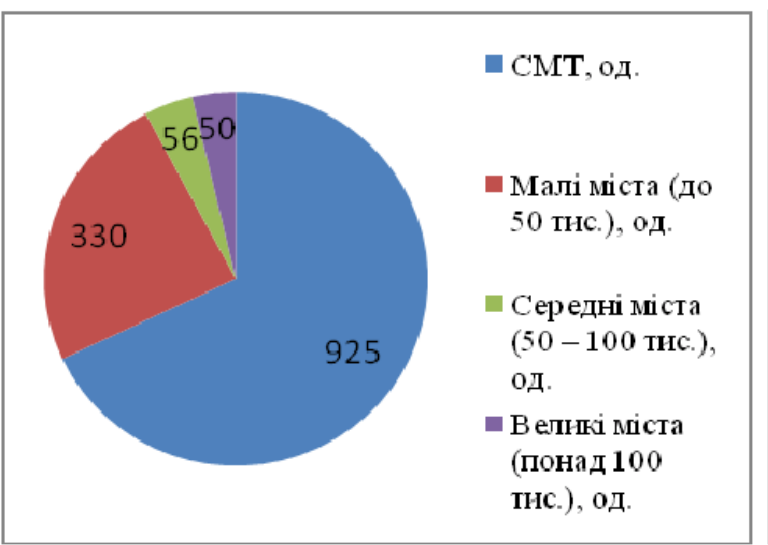
2014 рік

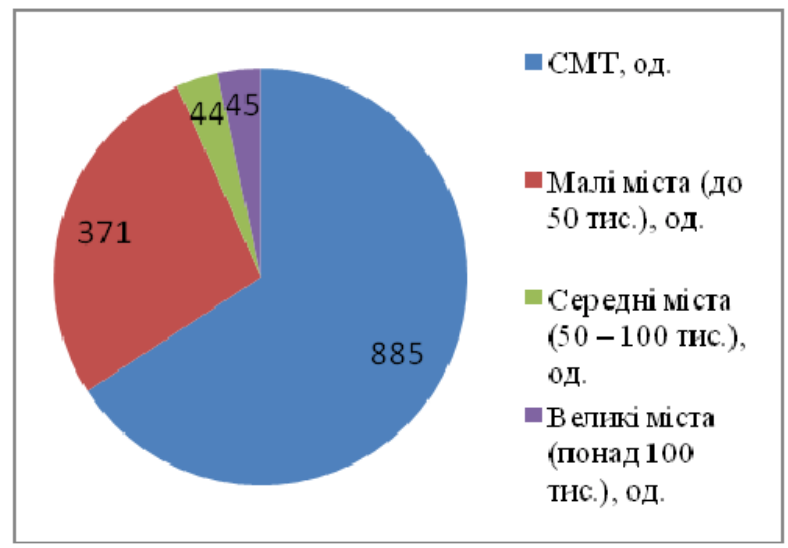

Рис. 2. Структура міських поселень України у 1991 та 2014 рр. [6]

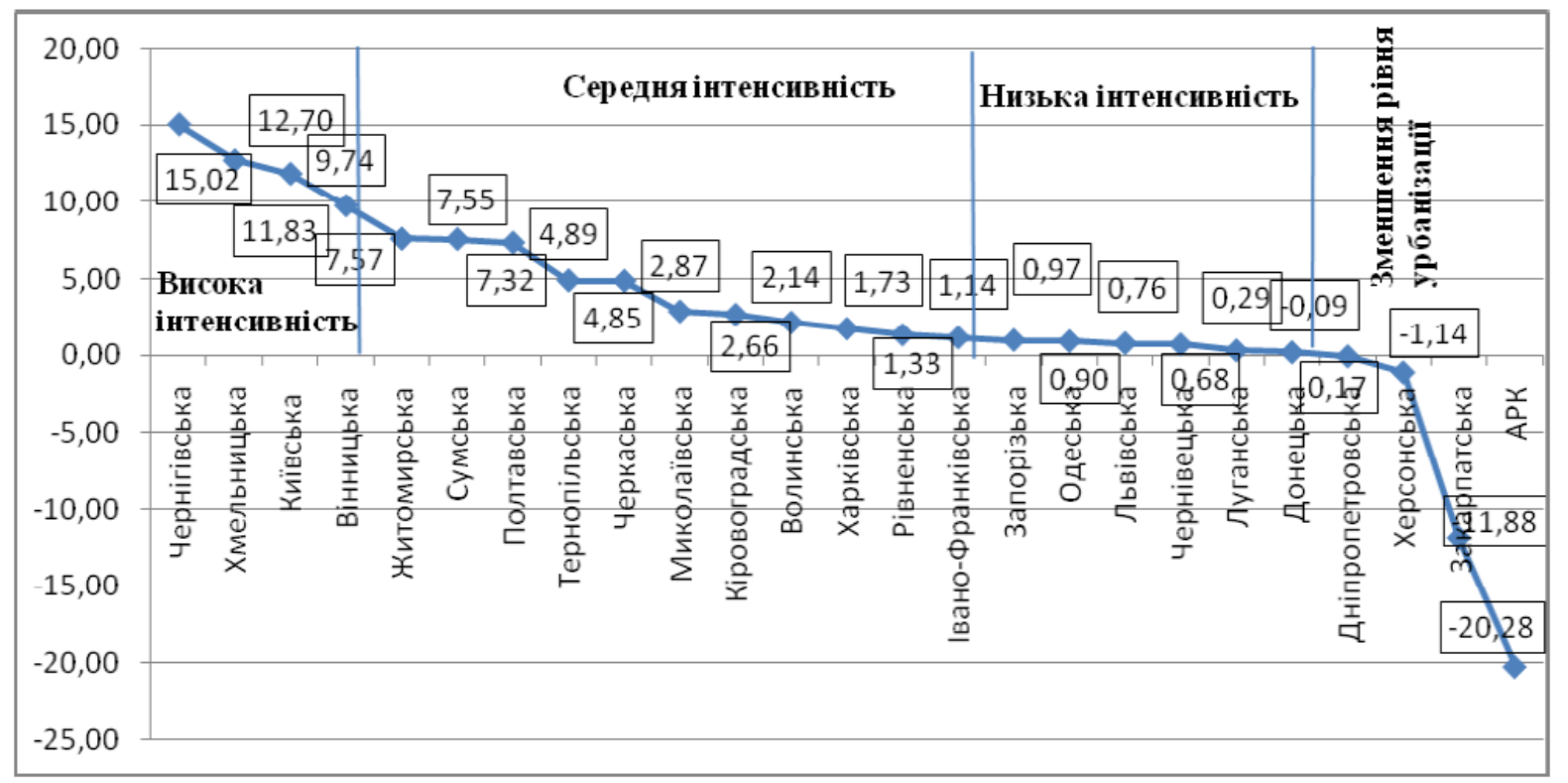

Рис. 3. Диференціація регіонів України за інтенсивністю урбанізації за 1991 - 2014 рр. 
було викликано надмірною концентрацією ресурсів держави, у т.ч. людських, на не завжди економічно виправданих великих будівлях соціалізму i справжне міське середовище, сучасна «міська» економіка у таких містах продовжує формуватися. Наслідки такої, у багатьох випадках «моноіндустріальної», урбанізації у ринкових умовах несуть великі соціальні загрози: це i зростання безробіття, i поява неорганізованого сектора 3 масою дрібних підприємств у сфері виробництва та обслуговування, зокрема у торгівлі. Міське господарство, комунальні служби, транспортна інфраструктура не завжди справляються iз зростаючими потребами [3]. Це ознаки так званої радянської «псевдоурбанізації», відмінної від псевдоурбанізації країн, що розвиваються, де вона зумовлена «виштовхуванням» населення з сільських районів через відносне їх аграрне перенаселення. Для України, як і для сусідніх пострадянських країн, псевдоурбанізаційні ознаки виявляються на рівні несформованості міського (у першу чергу культурного i обслуговуючого великий простір) середовища, відсутності міського менталітету населення, нездатності міст забезпечити прибуваюче сюди (наразі через кращі умови для працевлаштування) населення всією необхідною інфраструктурою.

Висновки. Таким чином, особливістю процесу урбанізації в Україні $є$ значний розрив між і1і кількісними та якісними параметрами. У розвинених країнах урбанізація зумовлюються не лише переселенням у міста основної маси населення, його концентрацією у великих містах тощо (кількісний аспект), а й поширенням та ствердженням міського способу життя як невід'ємного феномену сучасної цивілізації (якісний аспект урбаністичної еволюції). В Україні ще не завершено процес адаптації сільських жителів до міського способу життя, оволодіння ними відповідною системою цінностей, норм поведінки тощо. Незавершений характер урбанізації визначається також і тим, що значна частина міського населення за характером зайнятості, рівнем обслуговування, різноманітністю дозвілля тощо не повністю опанувала міський спосіб життя. Отже, важливість

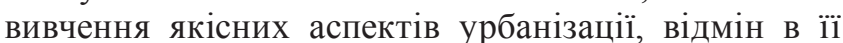
рисах у різних регіонах України набуває особливої актуальності.

\section{References:}

1. Nacional'nij Atlas Ukraïni [National Atlas of Ukraine]. Kyiv, SSIE "Kartographia”, 2007, 440 p. (In Ukrainian).

2. Posac'kij B. S. Osnovi urbanìstiki. Častina I. Urbanizaciâ ta teritorìal’ne rozplanuvannâ: Navčal'nij posibnik [Fundamentals of urban studies and planning. Part I. Urbanization and spatial planning. Textbook]. Second revised edition. Lviv, 2002, 120 p. (In Ukrainian).

3. Rudenko L. G., Savčuk I. G. Ukraina: izmeneniâ gorodskogo prostranstva [Ukraine: changes of urban space]. Ukraïns'kij geografičnij žurnal [Ukrainian Geographical Journal], 2013, Vol. 2, p. 48. (In Russian).

4. Salij İ. M. Urbanizaciâ v Ukraïni: social'nij ta upravlins'kij aspekti [Urbanization in Ukraine social and managerial aspects]. Kyiv, 2005, 302 p. (In Ukrainian).

5. Sociologiâ: korotkij enciklopedičnij slovnik [Sociology: brief encyclopedic dictionary]. General edition: V.İ. Volovič. Kyiv, 1998, p. 649. (In Ukrainian).

6. Statističnij zbirnik «Ukraïna u cifrah 2014» [Statistical bulletin "Ukraine in figures, 2014”]. Ed.: İ. M. Žuk. Kyiv, State Statistics Service of Ukraine, 2015, p. 165. (In Ukrainian).

7. Teritorial'nij rozvitok ta regional'na politika v Ukraïni [Territorial development and regional policy in Ukraine]. Scientific editor: V. S. Kravciv. Lviv, M. I. Dolishniy Institute of Regional Research of the NAS of Ukraine, 2015, 246 p. (In Ukrainian). 